\title{
THE EVOLUTIONARY HISTORY OF PARTHENOGENETIC CNEMIDOPHORUS LEMNISCATUS (SAURIA, TEIIDAE). I. EVIDENCE FOR A HYBRID ORIGIN
}

\author{
Jack W. Sites, Jr., ${ }^{1}$ Denise M. Peccinint-Seale, ${ }^{2}$ Craig Moritz, ${ }^{3,5}$ \\ JoHN W. WRIGHT, ${ }^{4}$ AND Wesley M. BROWN ${ }^{3}$ \\ 'Department of Zoology, Brigham Young University, Provo, UT 84602, USA \\ ${ }^{2}$ Departamento de Biologia, Instituto de Biociencias, Universidade de Sao Paulo, 05499, Sao Paulo, BRAZIL \\ ${ }^{3}$ Laboratory of Molecular Systematics, Museum of Zoology, and Department of Biology, \\ University of Michigan, Ann Arbor, MI 48109, USA \\ ${ }^{4}$ Herpetology Section, Museum of Natural History, 900 Exposition Boulevard, \\ Los Angeles, CA 90007, USA
}

\begin{abstract}
Chromosomes and allozymes were studied from chromosomally distinct unisexual (races $\mathrm{B}$ and $\mathrm{C}$ ) and bisexual (races D and E) populations of the teiid lizard Cnemidophorus lemniscatus, and from selected outgroup taxa (C. murinus, $C$. nigricolor, Ameiva ameiva, and $A$. auberi). Karyotyping confirmed the racial identity of individuals and showed that the chromosomal composition of populations at specific localities has remained the same for 20 years. All individuals of both unisexual populations were heterozygous for a pericentric inversion that distinguishes $D$ and $E$ bisexuals. Also, the unisexuals were all heterozygous for 8 of 11 protein loci for which $D$ and $E$ were fixed or nearly fixed for different alleles. Most of these alleles represent derived states relative to the other Cnemidophorus and Ameiva analyzed, and the fixed heterozygote condition at these nine markers provides unequivocal support for the hypothesis that the unisexual $C$. lemniscatus arose by hybridization between ancestors genetically similar to extant $D$ and $E$ populations. At the remaining three loci for which $\mathrm{D}$ and $\mathrm{E}$ show fixed differences, the unisexuals were homozygous rather than heterozygous. This suggests that either (1) allozymes have been lost by mutations to null, silent, or convergent mobility states, (2) ancestral genotypes were similar to but not identical with the extant $\mathrm{D}$ and $\mathrm{E}$ races, and/or (3) limited recombination may occur between unisexual genomes.

Allozyme-based genetic distances between $\mathrm{D}$ and $\mathrm{E}$ were large, suggesting that bisexual races $\mathrm{D}$ and $\mathrm{E}$ are genetically isolated; each race should be accorded full species status. This conclusion is supported by the absence of any clear biochemical evidence for their monophyly with respect to the other Cnemidophorus examined. Cladistic analyses of 17 phylogenetically informative loci revealed two equally parsimonious shortest trees, one supporting monophyly and the other paraphyly of the $C$. lemniscatus complex. Further testing of the monophyly of $C$. lemniscatus requires additional data. With the present study, the evidence that all parthenogenetic Cnemidophorus are of hybrid origin is complete.
\end{abstract}

Received January 10, 1989. Accepted October 1, 1989.

Unisexual organisms have received increased attention from evolutionary biologists because of the various degrees to which they depart from the normal mode of sexual reproduction that dominates the animal kingdom (Williams, 1975; White, 1978; Maynard Smith, 1978; Bell, 1982; Michod and Levins, 1988). Most unisexual vertebrates that have been carefully examined show strong evidence for hybrid genotypes (Schultz, 1969; Cole, 1975; Wright, 1978; Darevsky et al., 1985; Moritz and King, 1985; Vrijenhoek et al., 1989). However, it is widely recognized that not all unisexual animals arose by interspecific hybridiza-

\footnotetext{
${ }^{5}$ Present Address: Department of Zoology, University of Queensland, St. Lucia QLD 4067, Australia.
}

tion, especially among many invertebrate groups where spontaneous origins from a single bisexual population seem to be common (Suomalainen, 1950; Suomalainen et al., 1987). Within vertebrates, the causality of the relationship between interspecific hybridization and the origin of a new unisexual taxon has been disputed (Cuellar, 1974, 1977), and some possible exceptions have been proposed in the lizard families Gekkonidae (Lepidodactylus lugubris, Cuellar and Kluge, 1972; Pasteur et al., 1987), Xantusiidae (Lepidophyma flavimaculatus, Bezy, 1972; Bezy and Sites, 1987), Teiidae (Cnemidophorus lemniscatus, Vanzolini, 1970; Peccinini-Seale and Frota-Pessoa, 1974), and possibly Iguanidae (one population of Liolaemus chiliensis, Lamborot and Alvar- 
ez-Sarret, 1989). The origins of unisexual organisms by hybridization or by other means have important implications regarding the putative genetic/developmental and ecological constraints on their subsequent evolutionary success (Moritz et al., 1989; Vrijenhoek, 1989).

The possible nonhybrid origin of parthenogenetic Cnemidophorus lemniscatus is particularly significant since all other unisexual Cnemidophorus appear to have arisen by hybridization between well-differentiated bisexual species (Wright, 1978; Dessauer and Cole, 1989). Cnemidophorus lemniscatus ranges from lower Central America into northern South America, and extends into the Amazon Basin (Vanzolini, 1970; Peccinini, 1971; Hoogmoed, 1973 pp. 262-273; Serena, 1984, 1985). As currently defined, Amazonian C. lemniscatus from northern Brazil includes both diploid unisexual and bisexual populations, each containing multiple, cytogenetically recognizable groups that can be distinguished on the basis of chromosome number and/or morphology. The bisexual populations include two cytotypes (races D and E), each with $2 n$ $=50$ chromosomes, but that differ by a pericentric inversion in the largest chromosome pair (Peccinini-Seale and Frota-Pessoa, 1974). Three chromosome races of the Amazonian parthenogenetic populations, designated as $\mathrm{A}, \mathrm{B}$, and $\mathrm{C}$, have been recognized by these same authors, and all are heterozygous for the pericentric inversion that distinguishes bisexual races $\mathrm{D}$ and $\mathrm{E}$. Races $A$ and $B$ have $2 n=48$ chromosomes, one pair of microchromosomes less than race $C$, but differ from each other in the number of heteromorphic macrochromosome pairs (pairs 1 and 2 in A, pair 1 only in B). Further to the north, in Suriname, $C$. lemniscatus is represented by triploid unisexuals and diploid bisexuals (Serena, 1984, 1985). The bisexual Suriname populations have the same karyotype as the D chromosome race from the Brazilian Amazon Basin, while the triploids have a $3 n=75$ karyotype (Dessauer and Cole, 1989). Heterozygosity for the largest set of chromosomes and for several isozyme loci suggests that these triploids arose by hybridization between a $\mathrm{D}$ bisexual population and diploid unisexuals similar to the Amazonian C form (Dessauer and Cole, 1989). None of the diploid or triploid unisexuals is known to coexist with the bisexual populations (Peccinini-Seale, 1989).

Several competing hypotheses have been offered to explain the origin of the diploid unisexual populations. One possibility is that these arose spontaneously within one or more of the bisexual populations (Cuellar, 1974), or by other means as suggested by Peccinini-Seale and Frota-Pessoa (1974). Alternative suggestions include several hybridization hypotheses, such as the possibility of a cross between $C$. lemniscatus and the sympatric teiid Ameiva ameiva (Cole et al., 1983). However, the difference in adult body size between these species has led some to question the probability of such an event (Vanzolini, 1970; but see Cole et al., 1988), and isozyme data are also inconsistent, at least for Suriname populations (Dessauer and Cole, 1989). Another suggestion is that the unisexuals originated from hybridization between bisexual $C$. lemniscatus and a member of the $C$. sexlineatus species group (Darevsky et al., 1985), but there are substantial biogeographic problems with this argument (see also Dessauer and Cole, 1989). A final possibility is that the diploid parthenogens originated via hybridization between the $\mathrm{D}$ and $\mathrm{E}$ chromosome races of the bisexual form (Peccinini, 1971; Wright, 1978; Moritz and King, 1985; PeccininiSeale, 1989). Amazonian Cnemidophorus lemniscatus have thus far been treated as a single species, bat no bisexual populations have been found that are heteromorphic for a pericentric inversion in chromosome pair 1. This suggests the possibility that $D$ and E could be distinct, cytogenetically differentiated species. They could also simply be genetically differentiated intraspecific populations, but still hybridize and produce the meiotic and developmental changes necessary to successfully found a parthenogenetic population (Moritz, 1987; Moritz et al., 1989; Vrijenhoek, 1989).

Allozyme electrophoresis is a powerful technique for determining ancestry of unisexual organisms (reviewed by Suomolainen et al., 1987), but previous studies of the C. lemniscatus complex have not included all of the material required to address the above hypotheses about the origin of dip- 
TABLE 1. Taxa, localities and genetic characteristics [reproductive mode, chromosome race (corresponding to A-E of Peccinini-Seale and Frota-Pessoa, 1974), karyotype, sample sizes $(N) /$ number of cells analyzed (N.C.A.), chromosomal location of NORs (allozyme heterozygosity)] of bisexual (B) and unisexual (P) teiid lizards surveyed in this study and that of Vyas et al. (this volume).

\begin{tabular}{|c|c|c|c|c|c|c|c|}
\hline \multirow[b]{2}{*}{ No. ${ }^{a}$} & \multirow[b]{2}{*}{ Locality } & \multirow{2}{*}{$\begin{array}{l}\text { Repro- } \\
\text { ductive } \\
\text { mode }\end{array}$} & \multicolumn{4}{|c|}{ Cytogenetics } & \multirow{2}{*}{$\begin{array}{l}\text { Heterozygosity- } \\
\text { direct count }(N)\end{array}$} \\
\hline & & & Race & Karyotype $^{b}$ & N/N.C.A. & NOR & \\
\hline \multicolumn{8}{|c|}{ C. lemniscatus } \\
\hline 1. & Belem, Brazil & $\mathbf{P}$ & A & $48(2 ; 24 ; 22)$ & - & - & (mtDNA only) \\
\hline 2. & Oriximina, Brazil & $\mathrm{P}$ & B & $48(1 ; 25 ; 22)$ & $(11 / 137)$ & $1,2,7$ & $0.146(18)$ \\
\hline 3. & Maruda, Brazil & $\mathbf{P}$ & $\mathrm{C}$ & $50(1 ; 25 ; 24)$ & $(9 / 95)$ & 1 & $0.140(8)$ \\
\hline 4. & Capanema, Brazil & $\mathrm{P}$ & $\mathrm{C}$ & $50(1 ; 25 ; 24)$ & $(6 / 73)$ & 1 & $0.137(5)$ \\
\hline 5. & Alter do Chao, Brazil & B & $\mathrm{D}$ & $50(2 ; 24 ; 24)$ & $(6 / 97)$ & 1 & $0.024(9)$ \\
\hline 6. & Boa Vista, Brazil & B & $\mathrm{D}$ & $50(2 ; 24 ; 24)$ & $(4 / 68)$ & $i$ & $0.009(4)$ \\
\hline 7. & Urucurituba, Brazil & B & $\mathrm{E}$ & $50(0 ; 26 ; 24)$ & - & - & (mtDNA only) \\
\hline 8. & Manacapuru, Brazil & B & $\mathrm{E}$ & $50(0 ; 26 ; 24)$ & $(10 / 147)$ & 1 & $0.007(15)$ \\
\hline \multicolumn{8}{|c|}{ C. arubensis } \\
\hline 9. & Aruba, Netherlands Antilles & B & - & - & - & - & (mtDNA only) \\
\hline \multicolumn{8}{|c|}{ C. murinus } \\
\hline 10. & Curacao, Venezuela & B & - & - & - & - & $0.026(2)$ \\
\hline \multicolumn{8}{|c|}{ C. nigricolor } \\
\hline 11. & Isla La Blanquilla, Venezuela & B & - & - & - & - & $0.026(2)$ \\
\hline \multicolumn{8}{|c|}{ A. ameiva } \\
\hline 12. & Alter do Chao, ${ }^{c}$ Brazil & B & - & - & - & - & (mtDNA only) \\
\hline 13. & Manacapuru, ${ }^{c}$ Brazil & B & - & $50(0 ; 26 ; 24)$ & $(2 / 43)$ & $\begin{array}{l}1,4,9 \\
\text { micro }\end{array}$ & $0.053(5)$ \\
\hline \multicolumn{8}{|c|}{ A. auberi } \\
\hline 14. & Andros Island, Bahamas ${ }^{d}$ & B & & & - & & $0.041(6)$ \\
\hline
\end{tabular}

loid unisexuals (Dessauer and Cole, 1989; Peccinini-Seale, 1989). In this study, we compare chromosomes and allozymes of both bisexual forms (D and E) and the $B$ and $\mathrm{C}$ parthenogenetic populations from Brazilian Amazonia, and we estimate levels of genetic variability within, and divergence among, these forms. We also include samples of Cnemidophorus murinus and C. nigricolor, and as outgroups Ameiva ameiva and $A$. auberi. This paper complements the companion report by Vyas et al. (this volume) on mtDNA variation from these same and additional samples. The specific aims of this paper are (1) to test the hypothesis that the unisexuals arose via hybridization between the D and E bisexuals, and (2) to obtain data bearing on the specific status of the $D$ and $E$ bisexuals, i.e., are there one or two bisexual species in the $C$. lemniscatus complex in the Amazon valley?

\section{Methods \\ Sampling}

Natural populations of the Cnemidophorus lemniscatus complex and of Ameiva ameiva were sampled by D. M. PeccininiSeale and R. R. de Souza; Cnemidophorus murinus and $C$. nigricolor by J. Wright; and A. auberi by W. M. Brown. Table 1 summarizes geographic localities, sample sizes, cytogenetic data, and allozyme heterozygosity for all specimens. The localities of all samples except Ameiva auberi (from Andros Island, Bahamas) are plotted in Figure 1, and museum catalog numbers are given in Appendix 1.

Chromosomes were prepared from shortterm leukocyte cultures, in vitro bone marrow suspensions (Moritz, 1987), and intestinal epithelium (Peccinini-Seale, 1989), for silver nitrate (Howell and Black, 1980; Gold 


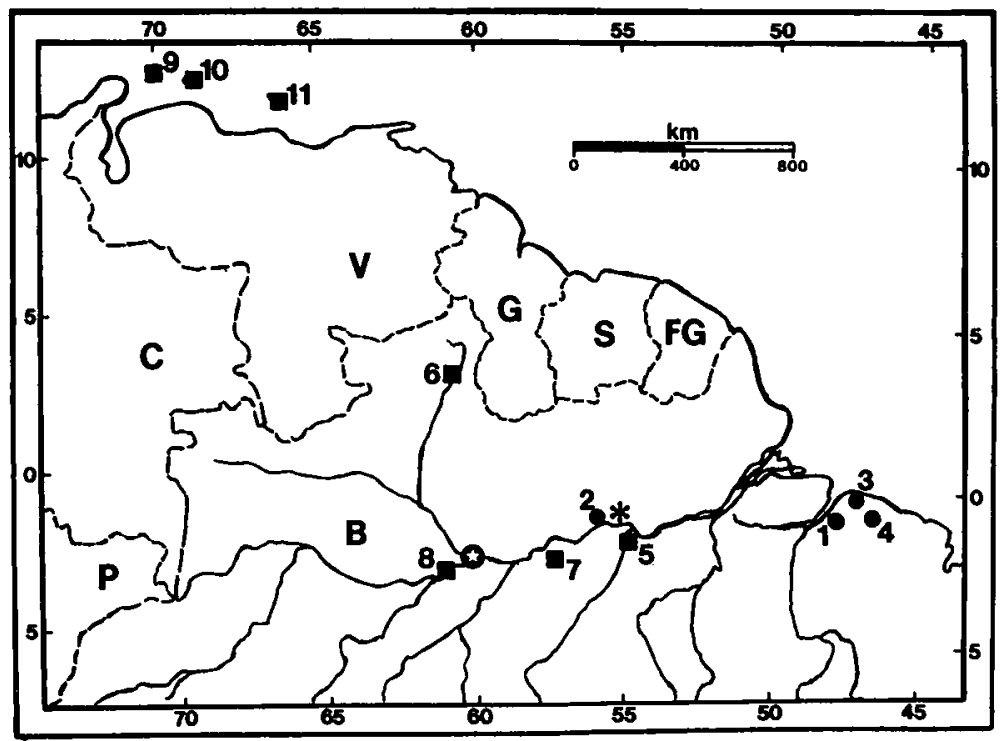

FIG. 1. Map of northern South America showing collecting localities for teiid lizards examined in this and the accompanying study (Vyas et al., this volume). Sample sizes and names of all locations are given in Table 1. Circles indicate locations of unisexual populations, squares denote bisexual populations, the star indicates the location of Manaus, and the asterisk represents Obidos-the site of the shift from bisexuality to unisexuality reported by Vanzolini (1970). International borders are marked with dashed lines, with countries denoted as follows: Peru (P), Colombia (C), Venezuela (V), Guyana (G), Suriname (S), French Guiana (FG), and Brazil (B).

and Ellison, 1983) and fluorescent (Schweizer, 1981) staining techniques. Heart and part of the liver were processed for mtDNA (Vyas et al., this volume), while intestine (duodenum), skeletal muscle, and the remaining liver were deep frozen for starch-gel electrophoresis.

\section{Allozyme Electrophoresis}

Homogenates of liver, muscle, and intestine samples for the allozyme analysis were prepared separately following Sites et al. (1988). Histochemical staining procedures followed Shaw and Prasad (1970), Selander et al. (1971), Harris and Hopkinson (1976), or Richardson et al. (1986). The specific buffer-stain-tissue combinations in which gene products were resolved are listed in Appendix 2. Enzyme commission (EC) numbers and nomenclature follow recommendations of the Nomenclature Committee of the International Union of Biochemistry (1984), and locus prefixes, abbreviations, and homologies follow Murphy and Crabtree (1985) to the extent that these could be reliably determined.

\section{Data Analysis}

Allozyme data were recorded as individual locus genotypes and analyzed with the BIOSYS-1 program of Swofford and Selander (1981). Genetic variability was estimated by average individual heterozygosity ( $H$, direct count), and between-sample divergence was summarized by the genetic distance coefficients of Nei (1978), Rogers (1972), and Hillis (1984). For purposes of phylogenetic analysis, loci were considered as characters and fixed allelic differences scored as alternative states (Buth, 1984). The resulting character matrix was analyzed using version 2.4.0 of PAUP (Swofford, 1985). The branch-and-bound algorithm (strict parsimony) was used to find the shortest trees, and all trees were rooted to a composite outgroup consisting of character states found in both species of Ameiva.

\section{RESULTS}

\section{Chromosome Analyses}

The number of lizards examined cytogenetically is summarized in Table 1. Con- 


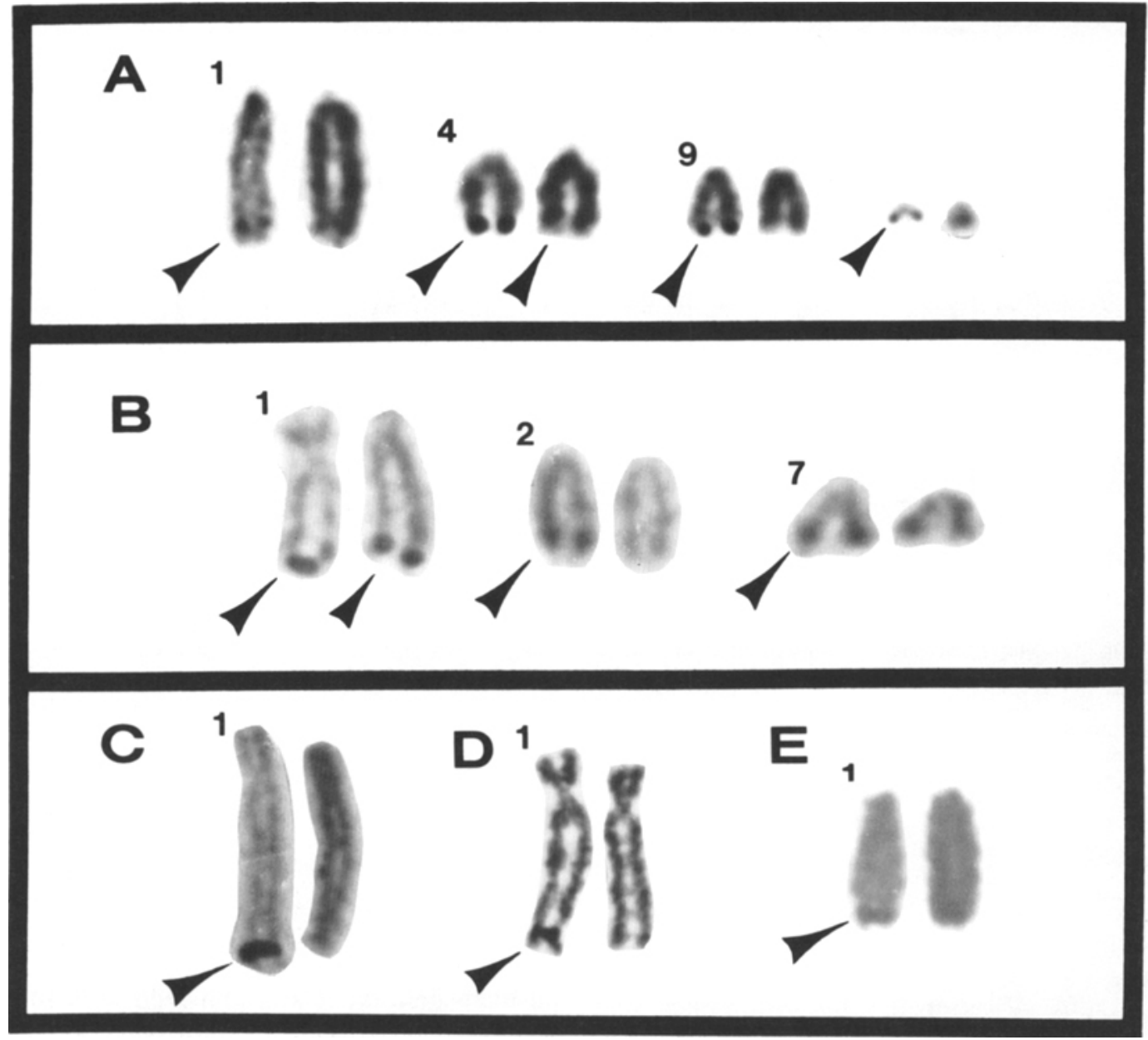

FIG. 2. Chromosomal localization of active NORs (arrows) in Ameiva amiva (A, Manacapuru), and in Amazonian $C$. lemniscatus: unisexual cytotypes B (Oriximina) and C (Capanema); and bisexual cytotypes D (Boa Vista) and E (Manacapuru). Numbers at upper left refer to macrochromosome pairs as identified by Peccinini-Seale and de Almeida (1986); note pair 1 heteromorphism in races B and C for fixed inversion difference between bisexuals $D$ and $E$.

ventionally stained metaphase plates yielded results consistent with those reported earlier by Peccinini-Seale and Frota-Pessoa (1974) and Peccinini-Seale and de Almeida (1986). In particular, the karyotypes in the 1987 samples were identical to those from samples from these same localities taken in 1970 and later (see also Peccinini, 1971; Peccinini-Seale, 1989). Silver nitrate staining for activity of nucleolus-organizing regions (NORs) in Amazonian populations surveyed in this study revealed variable patterns of NOR expression (Fig. 2). Results for pair-1 NOR expression are identical to those reported by Peccinini-Seale and de
Almeida (1986) and Peccinini-Seale (1989) in showing heterozygous activity at chromosome pair 1 in races $C, D$, and $E$. In contrast, the NOR pattern for race $B$, reported here for the first time, shows telomeric activity in both pair- 1 homologs, and additional activity in pairs 2 and 7 , the latter both being heterozygous in intensity of expression (Fig. 2). The Ameiva ameiva pattern from Manacapuru differed from that of previously studied localities, which displayed NOR activity in chromosome pairs $1,2,7,16,18,19$, and a microchromosome pair (Peccinini-Seale and de Almeida, 1986). Manacapuru specimens show varying de- 
TABle 2. Pairwise comparisons of two estimates of genetic distance (Nei, 1978, above diagonal; Hillis, 1984, below) for 10 samples of teiid lizards used in this study (localities as in Table 1).

\begin{tabular}{|c|c|c|c|c|c|c|c|c|c|c|}
\hline & \multicolumn{6}{|c|}{ C. lemniscatus } & \multirow{2}{*}{$\begin{array}{l}\text { C. murinus } \\
(10)\end{array}$} & \multirow{2}{*}{$\begin{array}{c}C . \\
\text { nigricolor } \\
(11)\end{array}$} & \multirow{2}{*}{ A. $\underset{(13)}{\text { ameiva }}$} & \multirow{2}{*}{$\begin{array}{l}\text { A. auber } \\
\text { (14) }\end{array}$} \\
\hline & $E(8)$ & $\mathrm{D}(6)$ & $\mathrm{D}(5)$ & B (2) & $C(3)$ & $C(4)$ & & & & \\
\hline 8 & - & 0.208 & 0.217 & 0.074 & 0.078 & 0.071 & 0.299 & 0.289 & 0.656 & 0.961 \\
\hline 6 & 0.211 & - & 0.004 & 0.052 & 0.051 & 0.051 & 0.416 & 0.242 & 0.683 & 0.814 \\
\hline 5 & 0.218 & 0.007 & - & 0.053 & 0.049 & 0.053 & 0.416 & 0.251 & 0.691 & 0.819 \\
\hline 2 & 0.076 & 0.057 & 0.056 & - & 0.000 & 0.000 & 0.322 & 0.243 & 0.622 & 0.855 \\
\hline 3 & 0.082 & 0.056 & 0.053 & 0.002 & - & 0.000 & 0.321 & 0.245 & 0.622 & 0.852 \\
\hline 4 & 0.078 & 0.060 & 0.061 & 0.002 & 0.005 & - & 0.314 & 0.244 & 0.622 & 0.842 \\
\hline 10 & 0.302 & 0.421 & 0.420 & 0.326 & 0.327 & 0.324 & - & 0.288 & 0.747 & 1.013 \\
\hline 11 & 0.293 & 0.248 & 0.255 & 0.248 & 0.251 & 0.255 & 0.294 & - & 0.701 & 1.012 \\
\hline 13 & 0.660 & 0.688 & 0.695 & 0.627 & 0.628 & 0.632 & 0.753 & 0.707 & - & 0.606 \\
\hline 14 & 0.964 & 0.819 & 0.822 & 0.859 & 0.858 & 0.852 & 1.018 & 1.018 & 0.611 & - \\
\hline
\end{tabular}

grees of NOR activity in pairs $1,4,9$, and a microchromosome pair (top idiogram of Fig. 2). Fluorescent banding (CMA and DADAPI counterstaining) did not reveal strongly fluorescent or negatively staining regions (data not shown).

\section{Allozyme Variation}

A total of 57 presumed structural gene products were consistently resolved across all taxa and populations sampled in this study (see footnote to Appendix 2). Fifteen loci were monomorphic across all samples: $M$-Acon-A, Ak-A, M-Aat-A, Ald-1, Ck-A, Ap-A, Est-5, Fum-A, Gp-1, $\beta$-Gluc-A, Gtdh$A, L d h-A, L d h-B, M d h-2$, and Pgm-1. A single individual of Ameiva auberi was heterozygous at the $D l d h-A$ locus, but otherwise this system was also invariant. Allele frequencies for the remaining 40 variable loci form three hierarchical categories with respect to levels of variation (Appendix 2): loci varying within C. lemniscatus, loci uniform within $C$. lemniscatus but varying among Cnemidophorus, and loci uniform among Cnemidophorus but differing in one or both Ameiva.

Twenty-one loci exhibit some degree of variation within and between populations of $C$. lemniscatus. The bisexual $\mathrm{D}$ and $\mathrm{E}$ samples show fixation or near fixation for alternate alleles at 11 loci $[S$-Aat- $A, A d a-A$, Cat-A, Est-1, Icdh-2, Iddh-A, S-Me-A, Pep(lla), Pep(lgg), Pep(pat), and Pgm-2; Appendix 2]. Sample $E$ is polymorphic at $S$-Acon-A, Est-2, Mpi-A, Pgm-2, and Sod1. One or both samples of the bisexual D populations show polymorphisms in $A d a-$
A, Ald-2, Est-1, Est-2, Pep(lla), Pgm-2, Pgk$A$, and $T p i-A$. Esterase-2 was highly polymorphic, and segregated two or three alleles in all six samples of $C$. lemniscatus.

The Nei (1978) genetic distance between the two samples (localities 5 and 6) of bisexual race $D$ is less than 0.01 , while that between race $E$ and the two $D$ samples is much higher (0.21-0.22; Table 2). By comparison, $C$. lemniscatus race $\mathrm{E}$ differs from C. murinus and $C$. nigricolor by Nei distances of 0.30 and 0.29 , respectively, while the race $D$ samples differ from these species by Nei distances of 0.42 and $0.24-0.25$, respectively (Table 2 ).

Relative to the bisexual populations, the three unisexual samples were more heterozygous, but less diverse within and between populations. All individuals showed fixed heterozygosity at six loci [S-Aat- $A, A d a-A$, Cat-A, Pep(lla), Pep(lgg), Pep(pat)], and close to fixed heterozygosity at two others $(I c d h-2, S-M e-A)$. At each of these loci, the heterozygous alleles are the same as those that distinguish $\mathrm{D}$ and $\mathrm{E}$ bisexuals (Appendix 2). The anodal gel slice illustrated in Figure 3 is representative of the isozyme patterns scored as heterozygous relative to the bisexuals. For two other loci at which the D and E bisexuals showed fixed differences, all unisexuals were fixed for the $\mathrm{D}$ allele (Est-1, Iddh-A; see cathodal slice in Fig. 3), and at the polymorphic Pgm-2 locus all unisexuals had only race $E$ alleles. The direct count heterozygosity $(H)$ estimates for the unisexual samples were between 0.14 and 0.15 (Table 1). In contrast, those for the three bisexual samples were between 


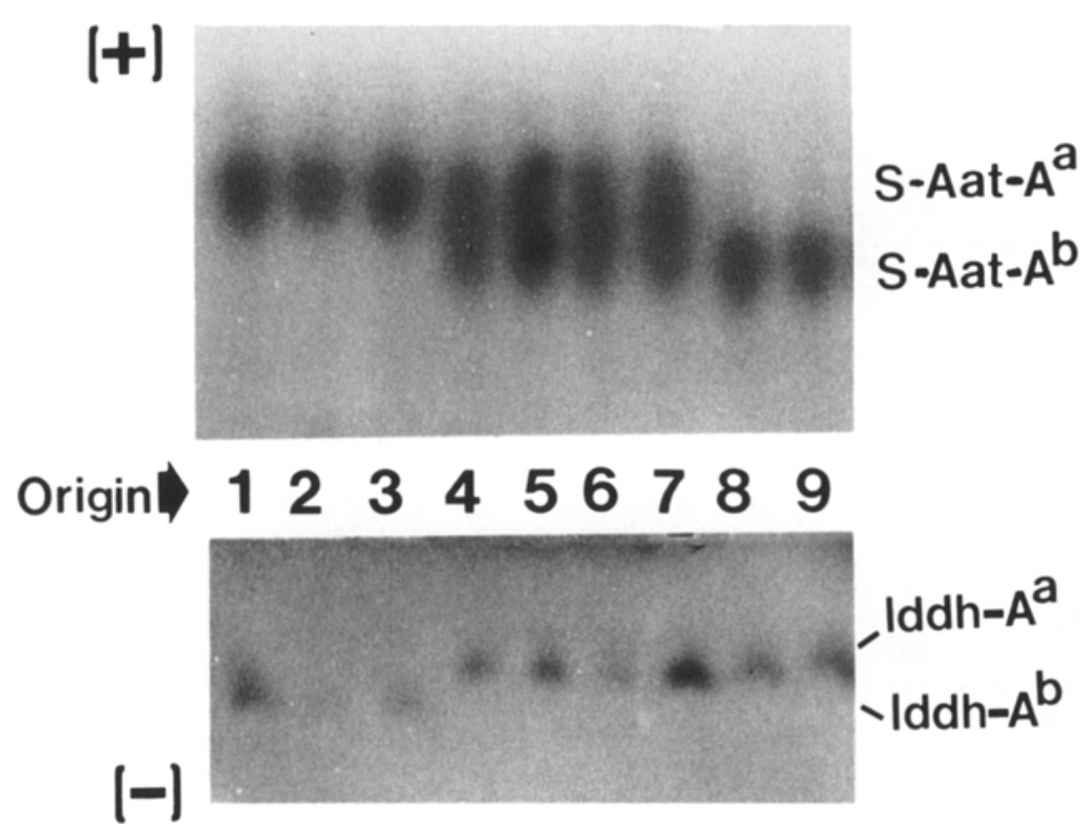

Fig. 3. Isozyme patterns expressed at two different enzyme loci for nine lizards run simultaneously on the same gel. The anodal slice shows the "fixed heterozygote" condition in unisexuals at the $S$-Aat- $A$ locus (lanes 4-7, all AB genotypes from race B) relative to fixed differences between bisexual races D (lanes 8-9, BB genotypes) and $\mathrm{E}$ (lanes 1-3, AA genotypes). The cathodal slice illustrates, for the same lizards, one of three loci (Iddh- $A$ ) in which the unisexuals electrophoretically resembled one bisexual genotype, even though races $D$ and $E$ were themselves fixed for different alleles.

0.01 and 0.02 (Table 1). $H$ values for the other species studied were 0.03 for both $C$. murinus and $C$. nigricolor, 0.04 for Ameiva auberi, and 0.05 for $A$. ameiva, although small sample sizes in most cases make these estimates tentative (see Table 1).

Genotypic diversity within and between the unisexual populations is fairly low. Multiple genotypes were scored at five loci, $S$-Acon-A, Icdh-2, Pgm-2, Pnp-A, and Tpi-A, but variation at the last two was due to single heterozygotes (Table 3 ). One common genotype was shared by the $\mathrm{B}$ and $\mathrm{C}$ chromosome forms (21 of 31 individuals), and six other genotypes were less frequent. Clonal diversity (D as calculated in Parker, 1979 ) is 0.5 , and the effective number of clones is 2.1 .

A second class of nine loci included those that were monomorphic or nearly so within the Amazonian Cnemidophorus lemniscatus complex, but differed in either $C . m u$ rinus or $C$. nigricolor, and possibly again in Ameiva. The loci in this group include $S$-Acon-A, Adh-A, $\beta$-Gal-A, $\beta$-Gluc- $A$, Glydh$A$, Hadh-A, Icdh-1, a-Mann-A, and Ntp-A.
Pnp-A displays the same alleles within all Cnemidophorus, but both $C$. murinus and $C$. nigricolor share a second allele at high frequencies that is either $\operatorname{rare}(P=0.03$ from locality 4) or absent from samples of C. lemniscatus.

The third class consists of 19 loci that were monomorphic (or nearly so) for the same mobility allele in all samples of Cnemidophorus, but fixed for different alleles in one or both species of Ameiva. These include $A l d-2, C k-C, E n o-A, F b p-A, G c d h-A$, G-3-pdh-A, G-h-pdh-1, Gpi-A, $\beta$-Glucur-A, $M d h-1, M-M e-A, M p i-A, P e p(p a p), P g d h-$ $A, P g k-A, P k-A, S o d-1, T p i-A$, and $U k-A$.

Several discrepancies are evident when the allozyme results of this study are compared with the earlier study of PeccininiSeale (1989). For example, Peccinini-Seale (1989) reported multiple $A D A$ genotypes for both the unisexual and bisexual $D$ samples she examined, whereas our data are unequivocal for fixed heterozygosity at this locus in all unisexuals we examined (Fig. 4). Additional discrepancies include (1) two "Pep-LA" loci reported by Peccinini-Seale 


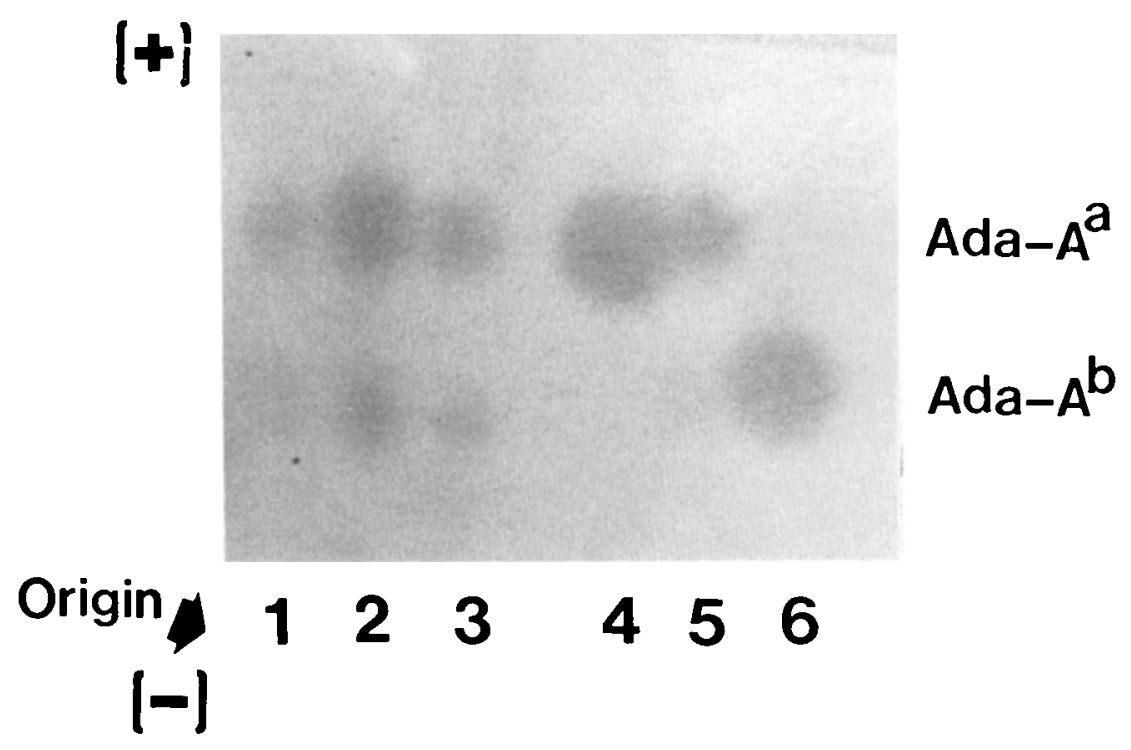

FIg. 4. Isozyme patterns of the $A D A$ locus, showing fixed heterozygote $\mathrm{AB}$ genotypes of unisexuals (lanes 1-3) relative to alternative homozygotes in the bisexuals (AA in lanes 4-5, race E; BB in lane 6, race $D$ ).

(1989), both variable within the unisexuals (her Table 4) whereas we found a single Pep (lla) locus for which unisexuals were all fixed heterozygotes for the same alleles (Appendix 2); (2) two Pep(lgg) loci reported by Peccinini-Seale (1989) to again show variation between the three unisexual races, versus the single locus resolved in this study showing fixed heterozygosity for the same alleles in races $B$ and $C$ (Appendix 2); and (3) the resolution of several loci $(A l b-1,-2$, -3 , and $P g m-3)$ by Peccinini-Seale (1989) showing variation within or among the unisexual samples, that were not included in this study. Another important sampling difference in these two studies was the inclusion of unisexual race $A$ in the survey of Peccinini-Seale (1989), which was not available to us and which differed from races $B$ and $\mathrm{C}$ at several loci. Further discrepancies could arise from sample size differences between the studies, temporal and/or spatial changes in allele frequencies, or in the case of the PEP loci, uncertainties of homology and/or misscoring of some loci (see Matson, 1989 , for an example of complex patterns of $P E P$ isozyme expression in birds).

\section{Phylogenetic Analysis}

If we accept the hypothesis that the unisexuals examined in this study are of hybrid origin (see below), we can then ask whether or not the alleles shared by the unisexuals and each of the bisexual races are derived, i.e., do they demonstrate phylogenetic relationship? To do this, we split the unisexual genotypes into homozygous D-like and E-like hypothetical genotypes (see also Moritz,

TABLE 3. Multilocus genotypes in samples of unisexual C. lemniscatus.

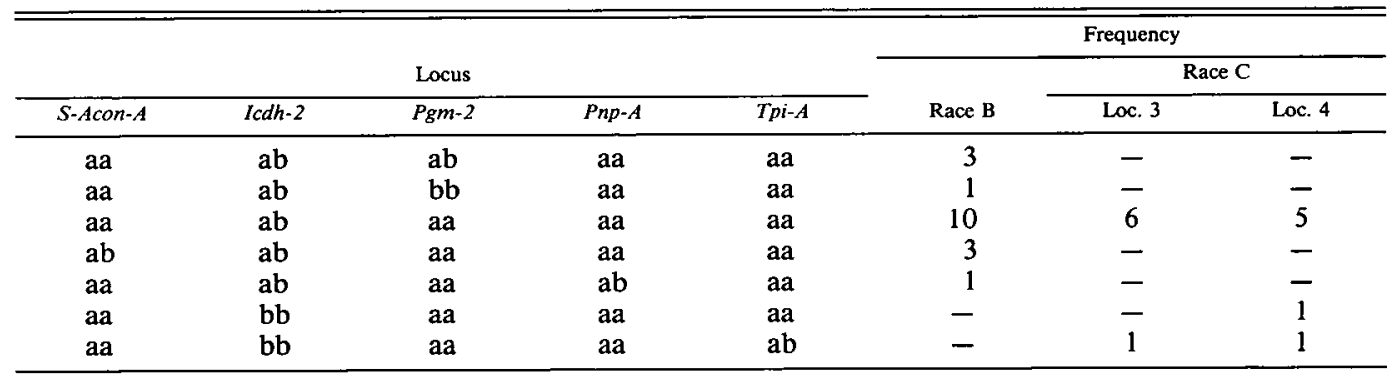



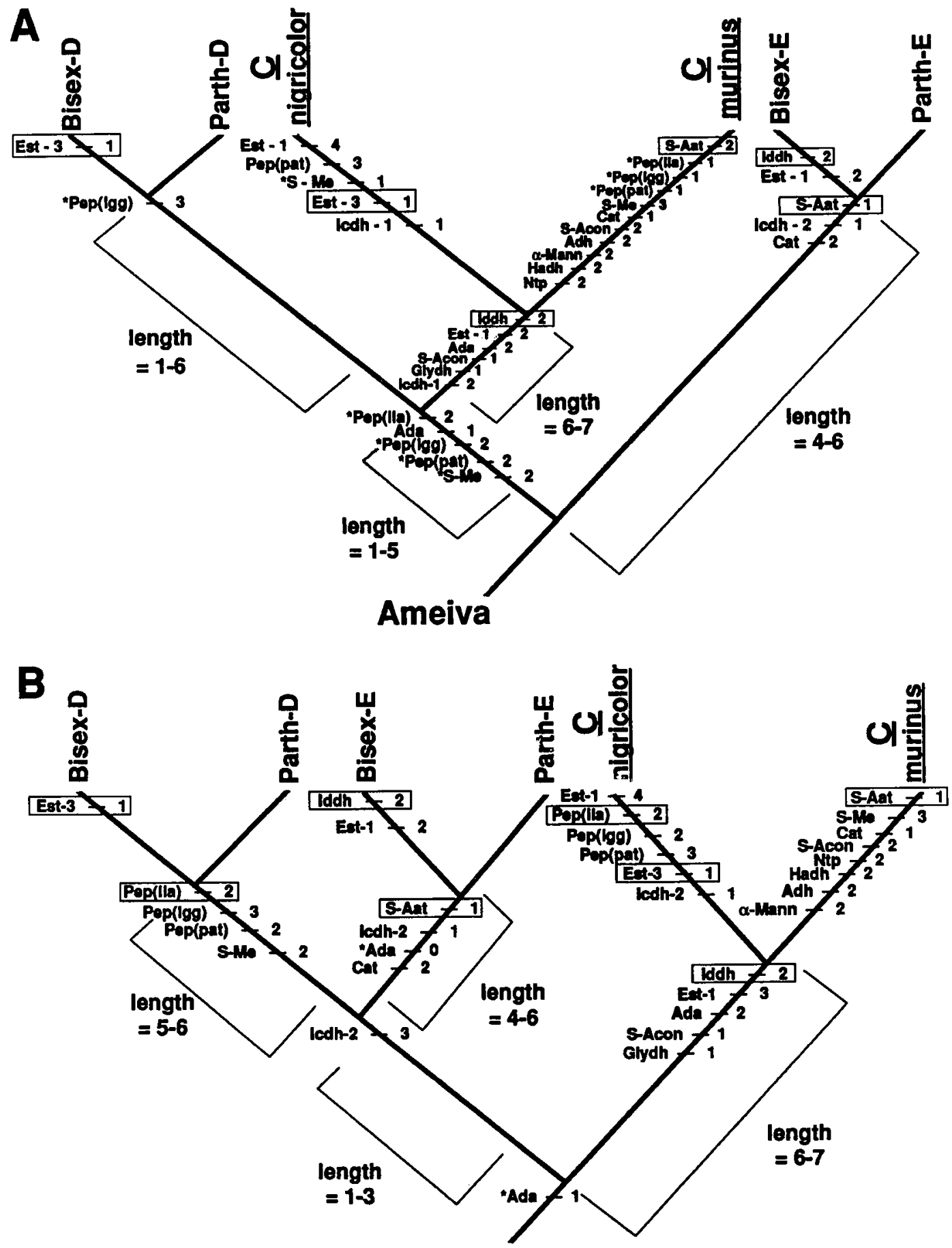

\section{Ameiva}

FIG. 5. Two equally parsimonious phylogenetic hypotheses for Cnemidophorus based on allozyme characters (consistency index $=0.77$, length $=52$ ). Character state changes along each branch refer to derived states identified for the informative loci in Appendix 2. Rectangles identify presumed homoplasious states, and asterisks $\left(^{*}\right)$ identify reversals in states. Fixed character states not illustrated at the base of tree A include $A d h-A(I), A l d-$ 2(1), Est-1(1), Est-2(2), Hadh- $A(I), I c d h-1(2), I d d h-A(I), \alpha-M a n n-A(I)$, and $N t p-A(I)$. Fixed character states for the base of tree B include all of those on tree A plus these four: $S$-Me-A(I), Pep(lgg) $(1), P e p(l l a)(I)$, and Pep(pat) (I). 
1987), determined character state polarities using the two Ameiva species as outgroups, and analyzed the derived states with PAUP.

This analysis revealed 17 phylogenetically informative loci (the characters) with 36 derived states (combinations of alleles); these are summarized in Appendix 2. Analysis using the branch-and-bound option of PAUP produced two shortest trees, each with a minimum of 52 steps and a consistency index of 0.77 (Fig. 5). Seven trees exist at 53 steps, and the consensus of these collapses the interior nodes of the two cladograms depicted in Figure 5, but retains the Bisex D-Parth D and Bisex E-Parth E clades.

Three patterns are evident in these sets of relationships. First, several derived states support the placement of each hypothetical parthenogenetic genome adjacent to its presumed bisexual parent. Second, several derived states support monophyly of $C . m u$ rinus $-C$. nigricolor, relative to the other Cnemidophorus studied. Third, there is no compelling evidence for monophyly of the C. lemniscatus complex. Tree B establishes monophyly for this group on the basis of a derived allele at the $I c d h-2$ locus. However, tree $\mathrm{A}$, which has the same number of steps, suggests paraphyly of $C$. lemniscatus with respect to the murinus-nigricolor clade, principally on the basis of a derived state in $A d a-A$. Additional data are required to resolve phylogenetic relationships of South American Cnemidophorus.

\section{Discussion \\ Origin of Unisexual C. lemniscatus Populations}

The $\mathrm{B}$ and $\mathrm{C}$ chromosome races of parthenogenetic $C$. lemniscatus are heterozygous at most loci ( 8 of 11) for which the bisexual $D$ and $E$ races are fixed (or almost fixed) for different alleles. Most of these alleles represent shared derived states relative to the other Cnemidophorus and Ameiva examined here. Together, these data provide strong evidence for a hypothesis of hybrid origin between genetically distinct ancestral $\mathrm{D}$ and $\mathrm{E}$ populations (Peccinini, 1971; Wright, 1978; Moritz and King, 1985).

At three additional loci where $\mathrm{D}$ and $\mathrm{E}$ differ, the unisexuals had only D-type (Est1 , Iddh-A) or only E-type alleles $(P g m-2)$. These patterns, which do not conform to the hybridization hypothesis, can be ex- plained by one or more of the three factors. First, allozymes from one parent may be lost by mutation to either a null or a convergent electromorph (Leslie and Vrijenhoek, 1980; Spinella and Vrijenhoek, 1982). A second possibility is that the actual parents involved were not identical to the extant $D$ and $E$ populations. This interpretation is compatible with the results of $\mathrm{mtDNA}$ analyses of these animals (Vyas et al., this volume). Third, preliminary cytological studies (Peccinini-Seale, unpub. data) suggest that meiosis may be normal up to first metaphase, allowing for limited recombination between the haploid genomes of the unisexuals. This could explain the observed patterns if the loci in question (i.e., those showing fixed differences between $D$ and $E$ ) were more distant from the centromere than those that have retained the predicted heterozygous genotypes (Asher, 1970).

Consistent with a hybrid origin, heterozygosity estimates averaged over 10 -fold higher for the unisexuals (range $=0.14-0.15$, $X=0.14$ ) than for the bisexuals (range $=$ 0.01-0.02, $X=0.01$; Table 1), even though absolute $H$ values were substantially lower than those reported for other unisexual Cnemidophorus. For example, Dessauer and Cole (1989) reported $H$ values ranging from 0.24 to 0.44 for other unisexual Cnemidophorus, and values in the range of 0.05 for bisexual species. These same authors surveyed C. lemniscatus populations in Suriname, and estimated $H$ values of 0.04 and 0.20 for bisexual and unisexual $(3 n)$ samples, respectively. Peccinini-Seale (1989) reported $H$ values ranging from 0.163 to 0.243 $(X=0.206)$ for three samples of diploid unisexual $C$. lemniscatus from the Amazon region, and $H=0.04$ for the single sample of bisexual race $D$ she examined. We suspect that the difference between our values and those reported in these two studies is largely a function of the different subsets of enzyme loci resolved in each study. Dessauer and Cole (1989) resolved 42 loci and Peccinini-Seale (1989) resolved 46, whereas we resolved 57 , and such differences could easily influence heterozygosity estimates (Simon and Archie, 1985).

The combination of allozyme and chromosome data collectively falsifies alternative hypotheses proposed to explain parthenogenesis in this complex. Darevsky et 
al. (1985) proposed, on the basis of published chromosomal evidence, that the unisexual $C$. lemniscatus may have originated by hybridization between a bisexual $C$. lemniscatus and a species of the $C$. sexlineatus group. This hypothesis is effectively refuted by the close relationship between the allozymes and chromosomes of the unisexuals and those of the type D and E bisexual Cnemidophorus. Similarly, the allozyme data refute the possibility of hybrid origin involving $A$. ameiva (see also Dessauer and Cole, 1989).

The hypothesis of a nonhybrid origin of the unisexuals has been suggested for Amazonian $C$. lemniscatus on the basis of distributional and chromosomal evidence (Vanzolini, 1970; Peccinini-Seale and Frota-Pessoa, 1974), and Cuellar (1974, 1977) specifically hypothesized a spontaneous origin within a bisexual species. Some workers have previously questioned the utility of chromosome markers as evidence for hybridization (Maslin, 1971), and PeccininiSeale and Frota-Pessoa (1974) proposed that a founder event might have fixed the chromosomal heteromorphism as a heterotic adaptation in the unisexual $C$. lemniscatus populations. Allozyme heterozygosity could then be increased by the mutational production of novel electromorphs (Parker and Selander, 1976; Vrijenhoek, 1984), but the low clonal diversity evident in the allozyme data set, and suggested by tissue grafting experiments (Serena, 1985), suggests that the unisexual $C$. lemniscatus may be of very recent origin (see also Vyas et al., this volume). No hypothesis other than origin via hybridization between $\mathrm{D}$ and $\mathrm{E}$ could simultaneously explain the evidence for a relatively recent origin and fixed heterozygosity at 9 marker loci ( 1 chromosome pair and 8 enzyme loci) for which the bisexuals show fixed differences. The silver-staining data (Fig. 2) do, however, suggest differentiation in the number of active NOR regions between the unisexual races since their origin.

\section{Status of the $D$ and E Bisexuals}

The allozyme data provide strong evidence that the $\mathrm{D}$ and $\mathrm{E}$ chromosome races of $C$. lemniscatus are distinct species. The Nei (1978) genetic distance between samples $D$ and $E$ was 20 -fold higher than that between samples of race $D$ collected from
Boa Vista and Alter do Chao and separated by a similar geographic distance. Indeed, the divergence between the $D$ and $E$ samples was only slightly lower than that between race $\mathrm{D}$ and $C$. nigricolor $(D=0.24)$, or race E and $C$. nigricolor $(D=0.29)$.

The genetic divergence between $\mathrm{D}$ and $\mathrm{E}$ can also be evaluated in the context of genetic distance estimates calculated from allozyme studies of other species of Cnemidophorus. Dessauer and Cole (1989). reported interspecific $D$ values ranging from 0.01 to 0.91 , with 14 of the 66 values in their matrix lower than that between $D$ vs. E C. lemniscatus (0.21), and seven others below 0.25 . Thus, the degree of divergence between bisexual races $D$ and $E$ is well within the range of about one-third of all pairwise distance comparisons published for morphologically recognized bisexual species of Cnemidophorus.

We conclude from such a comparison that the bisexual $D$ and $E$ chromosome races of C. lemniscatus are most likely genetically isolated units and should be accorded the status of separate species. This distinction is also evident from the absence of any clear biochemical evidence for their monophyly with respect to the other Cnemidophorus studied here (Fig. 5). More widespread sampling of the C. lemniscatus "complex" throughout northern South America will be necessary to clarify species boundaries in this group (studies in progress by $\mathrm{J}$. W. Wright).

The above analyses indicate that unisexual $C$. lemniscatus were formed by hybridization between the $\mathrm{D}$ and $\mathrm{E}$ bisexual taxa, and that these bisexuals should be considered as distinct species. With the results of this analysis, there is now strong evidence for the hybrid origin of all parthenogenetic forms of Cnemidophorus (see also Cole, 1975; Wright, 1978; Darevsky et al., 1985; Cole et al., 1988; Dessauer and Cole, 1989; Moritz et al., 1989). The same result appears to be present in other well studied vertebrate genera with multiple unisexual forms (e.g., Poecilia, Poeciliopsis, Menidia, Phoxinus, Heteronotia, Lacerta, Ambysto$m a$; reviewed by Vrijenhoek et al., 1989). The remaining exceptions to this general pattern (e.g., Lepidodactylus lugubris, Lepidophyma flavimaculatum, and Liolaemus chiliensis) need to be critically examined as 
to their putative nonhybrid origins that, if verified, would be highly significant.

\section{ACKNOWLEDGMENTS}

We thank W. E. Magnusson for his comments concerning taxonony of Amazonian Cnemidophorus, J. R. Dixon for examining specimens, and J. L. Sites for assistance with much of the electrophoretic work. We also thank P. Litz (Natural History Museum of Los Angeles County) and L. Garcia (Ecotropica) for field assistance in the Netherland Antilles and Venezuela, and T. d'Avila Pires (Museo Paraense Emilio Goeldi), W. E. Magnusson, and C. Morato (Institute Nacional de Pesquisas da Amazonia) for support of field work in Parà, Amazonas, and Roraima, and the children of Amazonia for assistance in collecting. Financial support was provided, in part, by grants from the National Science Foundation, the National Institutes of Health, the Fundacão de Amparo à Pesquisa do Estado de São Paulo, and the Conseho Nacional de Pesquisas, Brasil.

\section{Literature Cited}

AsHER, J. H. 1970. Parthenogenesis and genetic variability. II. One locus model for various diploid populations. Genetics 66:369-391.

BELL, G. 1982. The Masterpiece of Nature. CroomHelm, London, Canberra.

BEZY, R. L. 1972. Karyotypic variation and evolution of the lizards in the family Xantusiidae. Los Angeles Co. Museum Nat. Hist. Contrib. Sci. 227:1-29.

BEZY, R. L., AND J. W. SITES, JR. 1987. A preliminary study of allozyme evolution in the lizard family Xantusiidae. Herpetologica 43:280-292.

Buth, D. G. 1984. The application of electrophoretic data in systematic studies. Annu. Rev. Ecol. Syst. 15:501-22.

COLE, C. J. 1975. Evolution of parthenogenetic species of reptiles, pp. 340-355. In R. Reinboth (ed.), Intersexuality in the Animal Kingdom. Springer-Verlag, Heidelberg.

Cole, C. J., H. C. Dessauer, and C. R. Townsend. 1983. Isozymes reveal hybrid origin of neotropical unisexual lizards. Isozyme Bull. 16:74.

Cole, C. J., H. C. Dessauer, and G. F. BarrowCLOUGH. 1988. Hybrid origin of a unisexual species of whiptail lizard, Cnemidophorus neomexicanus in western North America: New evidence and a review. Am. Museum Novitates 2905:1-38.

Cuellar, O. 1974. On the origin of parthenogenesis in vertebrates: The cytogenetic factors. Am. Natur. 108:625-648.

1977. Animal parthenogenesis. Science 197: 837-843.

Cuellar, O., AND A. G. KLuge 1972. Natural parthenogenesis in the gekkonid lizard Lepidodactylus lugubris. J. Genet. 61:14-26.
Darevsky, I. S., L. A. Kupriyanova, AND T. Uzzell. 1985. Parthenogenesis in reptiles, pp. 412-526. In C. Gans and F. Billett (eds.), Biology of the Reptilia. Wiley, N.Y.

Dessauer, H. C., ANd C. J. Cole. 1989. Diversity between and within nominal forms of unisexual teiid lizards, pp. 49-70. In R. M. Dawley and J. P. Bogart (eds.), Evolution and Ecology of Unisexual Vertebrates. State Univ. New York Press, Albany, NY.

Gold, J. R., AND J. R. ElLISON. 1983. Silver staining for nucleolar organizing regions of vertebrate chromosomes. Stain Tech. 58:51-55.

HARRIS, H., AND D. A. HopkINSON. 1976. Handbook of Enzyme Electrophoresis in Human Genetics. North-Holland, Amsterdam.

HiLLIS, D. M. 1984. Misuse and modification of Nei's genetic distance. Syst. Zool. 33:238-340.

Hoogmoed, M. S. 1973. Notes on the Herpetofauna of Surinam. IV: The Lizards and Amphisbaenians of Surinam. Junk, The Hague.

Howell, W. M., AND D. A. BLACK. 1980. Controlled silver staining of nucleolus organizer regions with a protective colloidal developer: A one-step method. Experientia 36:1014-1015.

INTERNATIONAL UNION OF BIOCHEMISTRY, NOMENCLATURe COMMITTEe. 1984. Enzyme Nomenclature 1984. Academic Press, Orlando, FL.

Lamborot, M., and E. Alvarez-Sarret. 1989. Karyotypic characterization of some Liolaemus lizards in Chile (Iguanidae). Genome 32:393-403.

Leslie, J. F., AND R. C. VRiJenhoek. 1980. Consideration of Muller's Ratchet mechanism through studies of genetic linkage and genomic compatibilities in clonally reproducing Poeciliopsis. Evolution 34:1105-1115.

Maslin, T. P. 1971. Parthenogenesis in reptiles. Am. Zool. 11:361-380.

MASTON, R. H. 1989. Avian peptidase isozymes: Tissue distributions, substrate affinities, and assignment of homology. Biochem. Genet. 27:137-151.

Maynard Smith, J. 1978. The Evolution of Sex. Cambridge Univ. Press, London.

Michod, R. E., AND B. R. Levin (eds.) 1988. The Evolution of Sex. Sinauer, Sunderland, MA.

Moritz, C. 1987. Parthenogenesis in the tropical gekkonid lizard, Nactus arnouxii (Sauria: Gekkonidae). Evolution 41:1252-1266.

MorITZ, C., AND D. KING. 1985. Cytogenetic perspectives on parthenogenesis in the Gekkonidae, pp. 327-337. In G. Griff, R. Shine, and H. Ehrmann (eds.), Biology of Australasian Frogs and Reptiles. Roy. Zool. Soc., New South Wales, Sydney.

Moritz, C., W. M. Brown, L. D. Densmore, J. W. Wright, D. Vyas, S. Donnellan, M. Adams, and P. R. BAVERSTOCK. 1989. Genetic diversity and the dynamics of hybrid parthenogenesis in Cnemidophorus (Teiidae) and Heteronotia (Gekkonidae), pp. 87-112. In R. M. Dawley and J. P. Bogart (eds.), Evolution and Ecology of Unisexual Vertebrates. New York State Univ. Press, Albany, NY.

Murphy, R. W., and C. B. Crabtree. 1985. Evolutionary aspects of isozyme patterns, number of loci, and tissue specific gene expression in the prairie rattlesnake, Crotalus viridis viridis. Herpetologica $41: 451-470$.

NEI, M. 1978. Estimation of average heterozygosity 
and genetic distances from a small number of individuals. Genetics 89:583-590.

PARKER, E. D., JR. 1979. Ecological implications of clonal diversity in parthenogenetic morphospecies. Am. Zool. 19:753-762.

Parker, E. D., JR., AND R. K. Selander. 1976. The organization of genetic diversity in the parthenogenetic lizard Cnemidophorus tesselatus. Genetics 84:791-805.

Pasteur, G., J-F. Agnese, Ch. P. Bland, and N. PASTEUR. 1987. Polyclony and low relative heterozygosity in a widespread unisexual vertebrate, Lepidodactylus lugubris (Sauria). Genetica 75:7179.

PeCCININI, D. 1971. Chromosome variation in populations of Cnemidophorus lemniscatus in the Amazon Valley (Sauria, Teiidae). Cienc. Cult. 23:133136.

PeCcinini-Seale, D. 1981. New developments in vertebrate cytotaxonomy. IV. Cytogenetic studies in reptiles. Genetica 56:123-148.

. 1989. Genetic studies on the bisexual and unisexual populations of Amazonian Cnemidophorus, pp. 241-251. In R. M. Dawley and J. P. Bogart (eds.), Evolution and Ecology of Unisexual Vertebrates. New York State Univ. Press, Albany, NY.

Peccinini-Seale, D., and D. Frota-Pessoa. 1974. Structural heterozygosity in parthenogenetic populations of Cnemidophorus lemniscatus (Sauria: Teiidae) in the Amazonas valley. Chromosoma 27: 439-451.

Peccinini-Seale, D., ANd T. M. B. de Almeida. 1986. Chromosomal variation, nucleolar organizers, and constitutive heterochromatin in the genus Ameiva and Cnemidophorus (Sauria, Teiidae). Caryologia 39:227-237.

Richardson, B. J., P. R. Baverstock, AND M. Adams. 1986. Allozyme Electrophoresis. Academic Press, Orlando, FL.

Rogers, J. S. 1972. Measures of genetic similarity and distance. Univ. Texas Special Publ. Genet. 7103: 145-153.

Schultz, R. J. 1969. Hybridization, unisexuality, and polyploidy in the teleost Poeciliopsis (Poeciliidae) and other vertebrates. Am. Natur. 103:605-619.

SCHWEIZER, D. 1981. Counterstain-enhanced chromosome banding. Human Genet. 57:10-14.

Selander, R. K., M. H. Smith, S. Y. Yang, W. E. JoHNSON, AND G. B. GENTRY, 1971. Biochemical polymorphism and systematics in the genus Peromyscus. I. Variation in the old field mouse (Peromyscus polionotus). Univ. Texas Publ. Genet. 7103 : 49-90.

SERENA, M. 1984. Distribution and habitats of parthenogenetic and sexual Cnemidophorus lemniscatus (Sauria: Teiidae) in Surinam. Copeia 1984: 713-719.

- 1985. Zoogeography of parthenogenetic whiptail lizards (Cnemidophorus lemniscatus) in the Guyanas: Evidence from skin grafts, karyotypes, and erythrocyte areas. J. Biogeog. 12:49-58.

Shaw, C. R., AND R. Prasad. 1970. Starch gel electrophoresis of enzymes-A compilation of recipes. Biochem. Genet. 4:297-320.

Simon, C., AND J. ARCHIE. 1985. An empirical demonstration of the lability of heterozygosity estimates. Evolution 39:463-467.
Sites, J. W., Jr., J. L. Camarillo, A. Gonzales, F. Mendoza, L. Javier, M. Mancilla, and G. LARA-GoNGORA. 1988. Allozyme variation and genetic divergence within and between three cytotypes of the Sceloporus grammicus complex (Sauria, Iguanidae) in central Mexico. Herpetologica 44: 297-307.

Spinella, D. G., AND VRyenhoek, R. C. 1982. Genetic dissection of clonally inherited genomes of Poeciliopsis. II. Investigation of a silent carboxylesterase allele. Genetics 100:279-286.

Suomalainen, E. 1950. Parthenogenesis in animals. Adv. Genet. 3:193-253.

Suomalainen, E., J. Lokki, AND A. Saura. 1987. Cytology and Evolution in Parthenogenesis. CRC Press, Boca Raton, FL.

SwOFFORD, D. L. 1985. PAUP: Phylogenetic analysis using parsimony. Users Manual. Illinois Natural History Survey, Champaign, IL.

SwoFFord, D. L., AND R. K. SElander. 1981. BIOSYS-1: A FORTRAN program for the comprehensive analysis of electrophoretic data in population genetics and systematics. J. Hered. 72:281-283.

VANzolini, P. E. 1970. Unisexual Cnemidophorus lemniscatus in the Amazonas valley: A preliminary note (Sauria, Teiidae). Pap. Avulsos Zool. 23:6368.

VRUENHOEK, R. C. 1984. Ecological differentiation among clones: The frozen niche variation model, pp. 217-231. In K. Wohrmann and V. Loschcke (eds.), Population Biology and Evolution. SpringerVerlag, Berlin.

-1989. Genetic and ecological constraints on the origins and establishment of unisexual vertebrates, pp. 24-31. In R. M. Dawley and J. P. Bogart (eds.), Evolution and Ecology of Unisexual Vertebrates. New York State Univ. Press, Albany, NY. VRuenhoek, R. C., R. M. DAwley, C. J. COLE, AND J. P. BOGART. 1989. A list of the known unisexual vertebrates, pp. 19-23. In R. M. Dawley and J. P. Bogart (eds.), Evolution and Ecology of Unisexual Vertebrates. New York State Univ. Press, Albany, NY.

WhITE, M. J. D. 1978. Modes of Speciation. W. H. Freeman, San Francisco, CA.

WhitT, G. S. 1970. Developmental genetics of the lactate dehydrogenase isozymes of fish. J. Exp. Zool. 175:1-35.

Williams, G. C. 1975. Sex and Evolution. Monogr. Pop. Biol. No. 8, Princeton Univ., Princeton, NJ.

Wright, J. W. 1978. Parthenogenetic lizards. Science 201:1152-1154.

Corresponding Editor: R.C. Vrijenhoek

\section{APPENDIX 1}

All lizards used in this study have been catalogued in the Los Angeles County Museum of Natural History (LACM), the Museu Paraense "Emilio Goeldi" (MPEG), or the University of Michigan Museum of Zoology (UMMZ). Specimens examined: Cnemidophorus lemniscatus: Cytotype B-Oriximina, Para, Brasil (MPEG 14652-56, UMMZ 183871-74, 183876-82, 184292, 184294); cytotype C-Capanema, Para, Brasil (MPEG 14666-69, UMMZ 184291); Maruda, Para, Brazil (MPEG 14660-64, UMMZ 184298-300); cy- 
totype D-Alter do Chao, Para, Brasil (MPEG 1465759, 14665, 14671-72, UMMZ 184296-97); Boa Vista, Roraima, Brasil (MPEG 14649-51, 14670); cytotype E-Manacapuru, Amazonas, Brasil (MPEG 14644-48, UMMZ 183883-87, 184293, 194295, 184301-303). Cnemidophorus murinus-Netherlands Antilles, Cu- racao (LACM 138125). Cnemidophorus nigricolorVenezuela, Isla Blanquilla (LACM 138126). Ameiva ameiva-Manacapuru, Amazonas, Brasil (UMMZ 183959-61, 184304-05); Ameiva auberi-Bahamas, Andros Island, Small Hope Bay (UMMZ 183962-67).

APPENDIX 2

TABLE A. Allele frequencies scored for variable loci in 10 samples of Cnemidophorus and Ameiva used in this study. $a, h$

\begin{tabular}{|c|c|c|c|c|c|c|c|c|c|c|c|}
\hline \multirow[b]{4}{*}{ Locus } & \multirow[b]{4}{*}{ Allele } & \multicolumn{6}{|c|}{ Cnemidophorus lemniscatus } & \multirow{4}{*}{$\begin{array}{c}\text { Cnemido- } \\
\text { phorus } \\
\text { murinus } \\
10 \\
(2) \\
\end{array}$} & \multirow{4}{*}{$\begin{array}{c}\text { Cnemido- } \\
\text { phorus } \\
\text { nigri- } \\
\text { color } \\
11 \\
(2)\end{array}$} & \multirow{4}{*}{$\begin{array}{c}\text { Ameiva } \\
\text { ameiva } \\
13 \\
(5)\end{array}$} & \multirow{4}{*}{$\begin{array}{c}\text { Ameiva } \\
\text { auberi } \\
14 \\
(6)\end{array}$} \\
\hline & & \multicolumn{3}{|c|}{ Bisexuals } & \multicolumn{3}{|c|}{ Unisexuals } & & & & \\
\hline & & \multirow{2}{*}{$\begin{array}{c}\mathrm{E} \\
8 \\
(15) \\
\end{array}$} & \multicolumn{2}{|c|}{$\mathrm{D}$} & \multirow{2}{*}{$\begin{array}{c}\text { B } \\
2 \\
(18) \\
\end{array}$} & \multicolumn{2}{|c|}{$\mathrm{C}$} & & & & \\
\hline & & & $\begin{array}{c}\mathbf{6} \\
(4)\end{array}$ & $\begin{array}{c}5 \\
(9) \\
\end{array}$ & & $\begin{array}{c}3 \\
(8) \\
\end{array}$ & $\begin{array}{c}4 \\
\text { (5) }\end{array}$ & & & & \\
\hline \multirow[t]{3}{*}{$S-A a t-a$} & $a-1$ & 1.00 & - & - & 0.50 & 0.50 & 0.50 & 1.00 & - & - & - \\
\hline & b-0 & - & 1.00 & 1.00 & 0.50 & 0.50 & 0.50 & - & 1.00 & 0.20 & 1.00 \\
\hline & c-0 & - & - & - & - & - & - & - & - & 0.80 & - \\
\hline \multirow[t]{4}{*}{$S-A \operatorname{con}-A$} & $a-0$ & 0.90 & 1.00 & 1.00 & 0.92 & 1.00 & 1.00 & - & - & - & 0.42 \\
\hline & b-0 & 0.10 & - & - & 0.08 & - & - & - & - & 1.00 & 0.58 \\
\hline & c-1 & - & - & - & - & - & - & - & 1.00 & - & - \\
\hline & $\mathrm{d}-2$ & - & - & - & - & - & - & 1.00 & - & - & - \\
\hline \multirow[t]{5}{*}{$A d a-A$} & $a-0$ & 1.00 & - & - & 0.50 & 0.50 & 0.50 & - & - & 1.00 & - \\
\hline & b-1 & - & 0.83 & 1.00 & 0.50 & 0.50 & 0.50 & - & - & - & - \\
\hline & $c-2$ & - & - & - & - & - & - & 1.00 & 1.00 & - & - \\
\hline & $\mathrm{d}-0$ & - & - & - & - & - & - & - & - & - & 1.00 \\
\hline & $\mathrm{e}$ & - & 0.17 & - & - & - & - & - & - & - & - \\
\hline \multirow[t]{3}{*}{$A d h-A$} & a-1 & 1.00 & 1.00 & 1.00 & 1.00 & 1.00 & 1.00 & - & 1.00 & - & 0.33 \\
\hline & b-0 & - & - & - & - & - & - & - & - & 1.00 & 0.67 \\
\hline & $c-2$ & - & - & - & - & - & - & 1.00 & - & - & - \\
\hline \multirow[t]{3}{*}{ Ald-2 } & $a-1$ & 1.00 & 1.00 & 0.94 & 1.00 & 1.00 & 1.00 & 1.00 & 1.00 & - & - \\
\hline & b & - & - & 0.06 & - & - & - & - & - & - & - \\
\hline & $c-0$ & - & - & - & - & - & - & - & - & 1.00 & 1.00 \\
\hline Cat $-I^{b}$ & $a-1,2$ & 1.00 & - & - & 0.50 & 0.50 & 0.50 & 0.75 & - & - & - \\
\hline & b-0 & - & 1.00 & 1.00 & 0.50 & 0.50 & 0.50 & 0.25 & - & - & 1.00 \\
\hline & $\mathrm{c}-0$ & - & - & - & - & - & - & - & 1.00 & 1.00 & - \\
\hline$C k-C$ & a & 1.00 & 1.00 & 1.00 & 1.00 & 1.00 & 1.00 & 1.00 & 1.00 & - & - \\
\hline & $b$ & - & - & - & - & - & - & - & - & 1.00 & - \\
\hline & c & - & - & - & - & - & - & - & - & - & 1.00 \\
\hline Eno-A & a & 1.00 & 1.00 & 1.00 & 1.00 & 1.00 & 1.00 & 1.00 & 1.00 & - & - \\
\hline & b & - & - & - & - & - & - & - & - & 1.00 & 1.00 \\
\hline Est-1 & a-1 & - & 0.88 & 1.00 & 1.00 & 1.00 & 1.00 & - & - & - & - \\
\hline & $b-0$ & - & - & - & - & - & - & - & - & 1.00 & - \\
\hline & c-2 & 1.00 & 0.12 & - & - & - & - & - & - & - & - \\
\hline & d-0 & - & - & - & - & - & - & - & - & - & 1.00 \\
\hline & e-3 & - & - & - & - & - & - & 1.00 & - & - & - \\
\hline & $f-4$ & - & $\overline{-}$ & - & - & - & - & - & 1.00 & - & - \\
\hline$E s t-2^{c}$ & a-1 & 0.46 & 0.33 & 0.07 & 0.25 & - & 0.50 & - & 0.25 & - & - \\
\hline & b-2 & 0.29 & - & 0.21 & 0.50 & 0.58 & 0.50 & 1.00 & - & - & - \\
\hline & c & 0.25 & 0.67 & 0.72 & 0.25 & 0.42 & - & - & 0.75 & - & - \\
\hline & d-0 & - & - & - & - & - & - & - & - & 1.00 & 0.50 \\
\hline & $e-0$ & - & - & - & - & - & - & - & - & - & 0.40 \\
\hline & f & - & - & - & - & - & - & - & - & - & 0.10 \\
\hline$F b p-A$ & a & 1.00 & 1.00 & 1.00 & 1.00 & 1.00 & 1.00 & 1.00 & 1.00 & 1.00 & - \\
\hline & b & - & - & - & - & - & - & - & - & - & 1.00 \\
\hline$\beta-G a l-A$ & a & 1.00 & 1.00 & 1.00 & 1.00 & 1.00 & 1.00 & - & - & - & 1.00 \\
\hline & b & - & $\overline{-}$ & - & - & - & - & 1.00 & 1.00 & 1.00 & - \\
\hline$G c d h-A$ & a & 1.00 & 1.00 & 1.00 & 1.00 & 1.00 & 1.00 & 1.00 & 1.00 & 1.00 & - \\
\hline & b & - & - & - & - & - & - & - & - & - & 1.00 \\
\hline$G-3-p d h-A$ & a & 1.00 & 1.00 & 1.00 & 1.00 & 1.00 & 1.00 & 1.00 & 1.00 & - & 1.00 \\
\hline & b & - & - & - & - & - & - & - & 0.90 & - & - \\
\hline & $\mathrm{c}$ & - & - & - & - & - & - & - & 0.10 & - & - \\
\hline
\end{tabular}


APPENDIX 2

Table A. Continued.

\begin{tabular}{|c|c|c|c|c|c|c|c|c|c|c|c|}
\hline \multirow[b]{4}{*}{ Locus } & \multirow[b]{4}{*}{ Allele } & \multicolumn{6}{|c|}{ Cnemidophorus lemniscatus } & \multirow{4}{*}{$\begin{array}{l}\text { Cnemido- } \\
\text { phorus } \\
\text { murinus } \\
10 \\
\text { (2) }\end{array}$} & \multirow{4}{*}{$\begin{array}{l}\text { Cnemido- } \\
\text { phorrus } \\
\text { nigri- } \\
\text { color } \\
11 \\
\text { (2) }\end{array}$} & \multirow{4}{*}{$\begin{array}{c}\text { Ameiva } \\
\text { ameiva } \\
13 \\
\text { (5) }\end{array}$} & \multirow{4}{*}{$\begin{array}{c}\text { Ameiva } \\
\text { auberi } \\
14 \\
(6) \\
\end{array}$} \\
\hline & & \multicolumn{3}{|c|}{ Bisexuals } & \multicolumn{3}{|c|}{ Unisexuals } & & & & \\
\hline & & \multirow{2}{*}{$\begin{array}{c}E \\
8 \\
(15)\end{array}$} & \multicolumn{2}{|c|}{$\mathrm{D}$} & \multirow{2}{*}{$\begin{array}{c}\text { B } \\
2 \\
(18)\end{array}$} & \multicolumn{2}{|c|}{$\mathrm{C}$} & & & & \\
\hline & & & $\begin{array}{l}6 \\
\text { (4) }\end{array}$ & $\begin{array}{c}5 \\
\text { (9) }\end{array}$ & & $\begin{array}{c}3 \\
(8)\end{array}$ & $\begin{array}{c}4 \\
\text { (5) }\end{array}$ & & & & \\
\hline$G-6-p d h-1$ & a & 1.00 & 1.00 & 1.00 & 1.00 & 1.00 & 1.00 & 1.00 & 1.00 & - & - \\
\hline & $\mathrm{b}$ & - & - & - & - & - & - & - & - & 1.00 & - \\
\hline & $\mathrm{c}$ & - & - & - & - & - & - & - & - & - & 1.00 \\
\hline Gpi-A & a & 1.00 & 1.00 & 1.00 & 1.00 & 1.00 & 1.00 & 1.00 & 1.00 & - & - \\
\hline & $\mathrm{b}$ & - & - & - & - & - & - & - & - & 1.00 & 1.00 \\
\hline$\beta$-Gluc- $A$ & $\mathbf{a}$ & 1.00 & 1.00 & 1.00 & 1.00 & 1.00 & 0.83 & - & - & 1.00 & - \\
\hline & $\mathrm{b}$ & - & - & - & - & - & 0.17 & 1.00 & - & - & 1.00 \\
\hline & c & - & - & - & - & - & - & - & 1.00 & - & - \\
\hline$\beta$-Glucur-A & a & 1.00 & 1.00 & 1.00 & 1.00 & 1.00 & 1.00 & 1.00 & 1.00 & - & - \\
\hline & b & - & - & - & - & - & - & - & - & 1.00 & - \\
\hline & c & - & - & - & - & - & - & - & - & - & 1.00 \\
\hline Glydh-A & $\mathrm{a}-0$ & 1.00 & 1.00 & 1.00 & 1.00 & 1.00 & 1.00 & - & - & 1.00 & 1.00 \\
\hline & b-1 & - & - & - & - & - & - & 1.00 & 1.00 & - & - \\
\hline Hadh-A & a-1 & 1.00 & 1.00 & 1.00 & 1.00 & 1.00 & 1.00 & - & 1.00 & - & - \\
\hline & b-2 & - & - & - & - & - & - & 1.00 & - & - & - \\
\hline & $\mathrm{c}-0$ & - & - & - & - & - & - & - & - & 1.00 & 1.00 \\
\hline$I c d h-I^{d}$ & $a-3$ & 1.00 & 1.00 & 1.00 & 1.00 & 1.00 & 1.00 & - & - & 0.30 & - \\
\hline & b-0 & - & - & - & - & - & - & - & - & 0.20 & - \\
\hline & $c-0$ & - & - & - & - & - & - & - & - & 0.50 & - \\
\hline & $d-0$ & - & - & - & - & - & - & - & - & - & 1.00 \\
\hline & e-1 & - & - & - & - & - & - & - & 1.00 & - & - \\
\hline & $f-2$ & - & - & - & - & - & - & 1.00 & - & - & - \\
\hline$I c d h-2^{e}$ & $a-1$ & 1.00 & - & - & 0.54 & 0.42 & 0.50 & - & - & - & - \\
\hline & $b-0$ & - & 1.00 & 1.00 & 0.46 & 0.58 & 0.50 & 1.00 & 1.00 & 0.90 & 1.00 \\
\hline & $\mathrm{c}-2$ & - & - & - & - & - & - & - & - & 0.10 & - \\
\hline$I d d h-A$ & a-1 & - & 1.00 & 1.00 & 1.00 & 1.00 & 1.00 & - & - & - & - \\
\hline & b-2 & 1.00 & - & - & - & - & - & 1.00 & 1.00 & - & - \\
\hline & $\mathrm{c}-0$ & - & - & - & - & - & - & - & - & 1.00 & 1.00 \\
\hline$M d h-1$ & a & 1.00 & 1.00 & 1.00 & 1.00 & 1.00 & 1.00 & 1.00 & 1.00 & 1.00 & - \\
\hline & b & - & - & - & - & - & - & - & - & - & 1.00 \\
\hline$M-M e-A$ & a & 1.00 & 1.00 & 1.00 & 1.00 & 1.00 & 1.00 & 1.00 & 1.00 & 1.00 & - \\
\hline & b & - & - & - & - & - & - & - & - & - & 1.00 \\
\hline$S-M e-A$ & a-1 & 1.00 & - & - & 0.55 & 0.50 & 0.50 & - & 1.00 & - & - \\
\hline & b-2 & - & 1.00 & 1.00 & 0.45 & 0.50 & 0.50 & - & - & - & - \\
\hline & $c-0$ & - & - & - & - & - & - & - & - & 1.00 & 1.00 \\
\hline & $\mathrm{d}-3$ & - & - & - & - & - & - & 1.00 & - & - & - \\
\hline$M p i-A$ & a & 0.97 & 1.00 & 1.00 & 1.00 & 1.00 & 1.00 & 1.00 & 1.00 & 0.90 & - \\
\hline & b & 0.03 & - & - & - & - & - & - & - & - & - \\
\hline & $\mathrm{c}$ & - & - & - & - & - & - & - & - & 0.10 & - \\
\hline & d & - & - & - & - & - & - & - & - & - & 1.00 \\
\hline$\alpha-\operatorname{Mann}-A$ & $a-1$ & 1.00 & 1.00 & 1.00 & 1.00 & 1.00 & 1.00 & - & 1.00 & - & - \\
\hline & $b-0$ & - & - & - & - & - & - & - & - & 1.00 & - \\
\hline & $c-0$ & - & - & - & - & - & - & - & - & - & 1.00 \\
\hline & $\mathrm{d}-2$ & - & - & - & - & - & - & 1.00 & - & - & - \\
\hline$N t p-A$ & $a-1$ & 1.00 & 1.00 & 1.00 & 1.00 & 1.00 & 1.00 & - & 1.00 & - & - \\
\hline & $b-0$ & - & - & - & - & - & - & - & - & 1.00 & - \\
\hline & c-0 & - & - & - & - & - & - & - & - & - & 1.00 \\
\hline & $\mathrm{d}-2$ & - & - & - & - & - & - & 1.00 & - & - & - \\
\hline Pep(lla f & $a-1$ & 1.00 & - & 0.06 & 0.50 & 0.50 & 0.50 & 1.00 & - & - & - \\
\hline & $b-2$ & - & 1.00 & 0.94 & 0.50 & 0.50 & 0.50 & - & 1.00 & - & - \\
\hline & $c-0$ & - & - & - & - & - & - & - & - & 1.00 & 1.00 \\
\hline$P e p(l g g)^{g}$ & $a-1,2$ & 1.00 & - & - & 0.50 & 0.50 & 0.50 & 1.00 & 0.25 & - & - \\
\hline & $b-3$ & - & 1.00 & 1.00 & 0.50 & 0.50 & 0.50 & - & 0.75 & - & 0.17 \\
\hline & $\mathrm{c}-0$ & - & - & - & - & - & - & - & - & 1.00 & - \\
\hline & $d-0$ & - & - & - & - & - & - & - & - & - & 0.83 \\
\hline$P e p(p a p)$ & a & 0.96 & 1.00 & 1.00 & 1.00 & 1.00 & 1.00 & 1.00 & 1.00 & - & - \\
\hline
\end{tabular}


APPENDIX 2

TABle A. Continued.

\begin{tabular}{|c|c|c|c|c|c|c|c|c|c|c|c|}
\hline \multirow[b]{4}{*}{ Locus } & \multirow[b]{4}{*}{ Allele } & \multicolumn{6}{|c|}{ Cnemidophorus lemniscatus } & \multirow{4}{*}{$\begin{array}{c}\text { Cnemido- } \\
\text { phorus } \\
\text { murinus } \\
10 \\
(2)\end{array}$} & \multirow{4}{*}{$\begin{array}{c}\text { Cnemido- } \\
\text { phorus } \\
\text { nigri- } \\
\text { color } \\
11 \\
(2)\end{array}$} & \multirow{4}{*}{$\begin{array}{c}\text { Ameiva } \\
\text { ameiva } \\
13 \\
(5)\end{array}$} & \multirow{4}{*}{$\begin{array}{c}\text { Ameiva } \\
\text { auberi } \\
14 \\
(6)\end{array}$} \\
\hline & & \multicolumn{3}{|c|}{ Bisexuals } & \multicolumn{3}{|c|}{ Unisexuals } & & & & \\
\hline & & \multirow{2}{*}{$\begin{array}{c}E \\
8 \\
(15)\end{array}$} & \multicolumn{2}{|c|}{$\bar{D}$} & $\bar{B}$ & \multicolumn{2}{|c|}{$\mathrm{C}$} & & & & \\
\hline & & & $\begin{array}{c}6 \\
(4)\end{array}$ & $\begin{array}{c}5 \\
(9)\end{array}$ & $\begin{array}{c}2 \\
(18)\end{array}$ & $\begin{array}{c}3 \\
(8)\end{array}$ & $\begin{array}{c}4 \\
(5)\end{array}$ & & & & \\
\hline & b & 0.04 & - & - & - & - & - & - & - & 1.00 & - \\
\hline & c & - & - & - & - & - & - & - & - & - & 0.92 \\
\hline & d & - & - & - & - & - & - & - & - & - & 0.08 \\
\hline \multirow[t]{5}{*}{ Pep(pat) } & $a-1$ & 1.00 & - & - & 0.50 & 0.50 & 0.50 & 1.00 & - & - & - \\
\hline & b-2 & - & 1.00 & 1.00 & 0.50 & 0.50 & 0.50 & - & - & - & - \\
\hline & $c-0$ & - & - & - & - & - & - & - & - & 1.00 & - \\
\hline & $d-0$ & - & - & - & - & - & - & - & - & - & 1.00 \\
\hline & $e-3$ & - & - & - & - & - & - & - & 1.00 & - & - \\
\hline \multirow[t]{2}{*}{$P g d h-A$} & a & 1.00 & 1.00 & 1.00 & 1.00 & 1.00 & 1.00 & 1.00 & 1.00 & 1.00 & - \\
\hline & b & - & - & - & - & - & - & - & - & - & 1.00 \\
\hline \multirow[t]{7}{*}{ Pgm-2 } & a & 0.97 & - & - & 0.86 & 1.00 & 1.00 & - & - & 0.90 & - \\
\hline & b & 0.03 & - & - & 0.14 & - & - & - & - & - & - \\
\hline & c & - & 0.75 & 0.33 & - & - & - & - & - & - & - \\
\hline & d & - & 0.25 & 0.67 & - & - & - & - & - & 0.10 & - \\
\hline & e & - & - & - & - & - & - & - & - & - & 0.30 \\
\hline & f & - & - & - & - & - & - & - & - & - & 0.70 \\
\hline & g & - & - & - & - & - & - & 1.00 & 1.00 & - & - \\
\hline \multirow[t]{2}{*}{$P g k-A$} & a & 1.00 & 0.88 & 1.00 & 1.00 & 1.00 & 1.00 & 1.00 & 1.00 & 1.00 & 0.25 \\
\hline & b & - & 0.12 & - & - & - & - & - & - & - & 0.75 \\
\hline \multirow[t]{3}{*}{$P k-A$} & a & 1.00 & 1.00 & 1.00 & 1.00 & 1.00 & 1.00 & 1.00 & 1.00 & - & - \\
\hline & b & - & - & - & - & - & - & - & - & 1.00 & - \\
\hline & c & - & - & - & - & - & - & - & - & - & 1.00 \\
\hline \multirow[t]{2}{*}{ Pnp-A } & $a$ & 1.00 & 1.00 & 1.00 & 0.97 & 1.00 & 1.00 & 0.50 & 0.25 & 0.60 & 1.00 \\
\hline & b & - & - & - & 0.03 & - & - & 0.50 & 0.75 & 0.40 & - \\
\hline \multirow[t]{3}{*}{ Sod-1 } & $\mathbf{a}$ & 0.97 & 1.00 & 1.00 & 1.00 & 1.00 & 1.00 & 1.00 & 1.00 & - & - \\
\hline & $\mathbf{b}$ & 0.03 & - & - & - & - & - & - & - & - & 1.00 \\
\hline & $c$ & - & - & - & - & - & - & - & - & 1.00 & - \\
\hline \multirow[t]{3}{*}{$T p i-A$} & $\mathrm{a}$ & 1.00 & 1.00 & 0.72 & 1.00 & 0.94 & 1.00 & 1.00 & 1.00 & 1.00 & - \\
\hline & $\mathbf{b}$ & - & - & 0.28 & - & 0.06 & - & - & - & - & - \\
\hline & $\mathrm{c}$ & - & - & - & - & - & - & - & - & - & 1.00 \\
\hline \multirow[t]{2}{*}{$U k-A$} & $\mathrm{a}$ & 1.00 & 1.00 & 1.00 & 1.00 & 1.00 & 1.00 & 1.00 & 1.00 & - & - \\
\hline & b & - & - & - & - & - & - & - & - & 1.00 & 1.00 \\
\hline
\end{tabular}

a Sample numbers, chromosome races, and sample sizes are as in Table 1 and Figure 1 . Numbers to the right of some alleles designate unordered character states in phylogenetically informative systems; alleles without accompanying numbers were unique and had not reached fixation and were not used in the phylogenetic analyses.

$b$ Derived states $1=a b, 2=a$ a

$c$ Derived state 1 includes aa and ab genotypes.

$d$ Plesiomorphic state 0 includes ac, be, and dd genotypes; $3=$ aa only.

State 2 = bc.

$f$ Derived states $1=a a, 2=b b$ and a single $a b$ heterozygote (locality 3 ).

$g$ Plesiomorphic state 0 includes two bd heterozygotes in $A$. auberi, derived state $2=a b$ in $C$. nigricolor.

$h$ Enzyme stains and electrophoretic conditions used to resolve 57 protein products across all taxa; specific multilocus systems are designated by prefixes $M$ and $S$ if mitochondrial and supernatant loci are known, or by suffixes " 1 ," " 2 ," etc., in order of decreasing anodal mobility if homologies are uncertain. Each enzyme is identified by the name recommended by the Nomenclature Committee of the International Union of Biochemistry (1984), followed by a parenthetic summary of the $\mathrm{EC}$ number, locus abbreviation(s), tissue code (I $=$ duodenum, $\mathrm{L}=\mathrm{liver}, \mathrm{M}=\mathrm{skeletal}$ muscle), (1984), followed by a parenthetic summary of the EC number, locus abbreviation(s), tissue code ( $=$ duodenum, $L=$ liver, $M=$ skeletal muscle), oH 8.2 and Tris-EDTA pH 8.0, respectively, of Selander et al., 1971). Aconitate hydratase (4.2.1.3, $M$ - $A$ con- $A, S$-Acon- $A$, L, A); adenosine deaminase pH 8.2 and Tris-EDTA pH 8.0, respectively, of Selander et al, 1971$)$. Aconitate hydratase $(4.2 .1 .3, M-A c o n-A, S$ - $A$ con- $A$, L, A); adenosine deaminase (3.5.4.4, $A d a-A, \mathrm{I}, \mathrm{B})$; adenylate kinase (2.7.4.3, $A k-A, \mathrm{M}, \mathrm{A})$; alcohol dehydrogenase $(1.1 .1 .1$, Adh-A, $\mathrm{L}$, C; pyruvate added to stain buffer to suppress
$L D H$ activity, second slice counterstained for $H A D H)$; aspartate aminotransferase $(2.6 .1 .1, M-A a t-A, S-A a t-A, \mathrm{~L}, \mathrm{~A})$; catalase $(1.11 .1 .6, \mathrm{Cat}-A$, L,

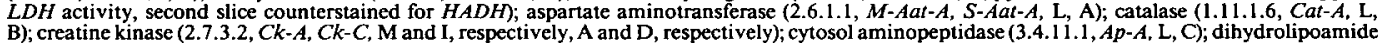

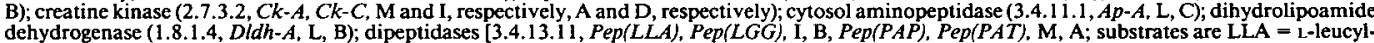
L-alanine, LGG = L-leucylglycylglycine, PAP = L-phenylalanyl-L-proline, and PAT = L-phenylalanyl-L-phenylalanyl-L-tyrosine); enolase (4.2.1.11, Eno-A, M, B); esterase [-, Est.-1, -2, -5, L, A (-I and -5), B (-2)]; fructose biphosphatase (3.1.3.11, Fbp- $A$, M, A); fructose-biphosphate aldolase (4.1.2 I 3, Ald- $I, A l d-2$, L and I, B and D, respectively); fumarate hydratase (4.2.7.2, Fum- $A, \mathrm{~L}, \mathrm{~A}$, counterstained for $M D H$ ); $\beta$-Galactosidase (3.2.1.23, $\beta-G a l$, ' ‘ ‘eneral protein' ( G-G-pdh-1, L, B); glucose-6-phosphate isomerase (S.3.1.9, Gpi-A, I, A); $\alpha$-Glucosidase $(3.2 .1 .20, \alpha$-Gluc-2, L, A); $\beta$-glucosidase $(3.2 .1 .21, \beta-G l u c-A$, $\mathrm{I}, \mathrm{A}) ; \beta$-glucuronidase $(3.2 .1 .31, \beta-G l u c u r-A, \mathrm{~L}, \mathrm{~B})$; glutamate dehydrogenase $(1.4 .1 .2, G t d h-A, \mathrm{~L}, \mathrm{~B}) ;$ glycerate dehydrogenase $(1.1 .1 .29, G l y d h-A . \mathrm{L}$, $\mathrm{A}$, pyruvate and pyrazole added to suppress $L D H$ and $A D H$, respectively); glycerol-3-phosphate dehydrogenase (1.1.1.8, G-3-pdh-A. M, A); $\mathrm{D}-2-$ hydroxyacid dehydrogenase (1.1.99.6, Hadh- $A, \mathrm{~L}, \mathrm{C})$; L-iditol dehydrogenase $(1.1 .1 .14$, Iddh- $A, \mathrm{~L}, \mathrm{~A})$; isocitrate dehydrogenase $(1.1 .1 .42, I c d h-1,-2$, $\mathrm{L}, \mathrm{A})$; L-lactate dehydrogenase $(1.1 .1 .27, L d h-A,-B, \mathrm{~L}, \mathrm{~A}) ;$ malate dehydrogenase $(1.1 .1 .37, M d h-1,-2, \mathrm{~L}, \mathrm{~A}) ;$ malic enzyme $(1.1 .1 .40, M-M e-A$, $S-M e-A, \mathrm{~L}$ and $\mathrm{M}, \mathrm{A}$ and $\mathrm{B}$, respectively); mannose-6-phosphate dehydrogenase (5.3.1.8, $M$ pi-A, L, A); $\alpha$-mannosidase (3.2.1.24, $\alpha-M a n n-A, \mathrm{~L}, \mathrm{~B})$; nucleoside-triphosphate pyrophosphatase $(3.6 .1 .19$, Ntp-A, L, B); phosphoglucomutase $(5.4 .2 .2, P g m-1,-2, \mathrm{~L}, \mathrm{~A})$; phosphogluconate dehydrogenase (1.1.1.44, Pgdh-A, M, A); phosphoglycerate kinase (2.7.2.3, Pgk-A, M, A); purine-nucleoside phosphorylase (2.4.2.1, Pnp-A, I, B); pyruvate kinase (2.7.1.40,Pk-A, M, B); superoxide dismutase (1.15.1.1, Sod-1, L, C); triosephospate isomerase (5.3.1.1, Tpi-A, I, A); and uridine kinase (2.7.1.48, $U k-A, \mathrm{M}, \mathrm{B})$ 